\title{
Awareness of Religious Tolerance for Millennial Youth in Surabaya in the Dynamics of Diversity
}

\author{
Siti Maizul Habibah ${ }^{1, *}$ Rr. Nanik Setyowati ${ }^{2}$ \\ ${ }^{1,2}$ Universitas Negeri Surabaya \\ "Corresponding author.Email: sitimaizulhabibah@upi.edu
}

\begin{abstract}
Indonesia in its development as a nation, all the uniqueness inherent in the multicultural Indonesian nation getsits ideological and philosophical umbrella from Pancasila. The millennial generation as citizens who have a strategic position, because of their intellectual capacity. For this reason, it is timefor efforts to build the moral values of the younger generation in the form of building a tolerant attitude, respecting diversity, developing respect for other social groups, and forming recognition of group diversity. This study aims to describe the awareness of religious tolerance of the Surabaya millennial generation in the dynamics of diversity. This research uses a qualitative approach with a qualitative descriptive design, data collection techniques by interview and the data analysis techniques are data presentation, data reduction and conclusion drawing. The results show awareness of religious tolerance in their surrounding environment, as evidenced by the construction of knowledge related to good tolerance and to the implementation of tolerance awareness in their respective environments
\end{abstract}

\section{Keywords—Religious tolerance, Diversity}

\section{INTRODUCTION}

Sociologically, the Indonesian nation contains a high level of pluralism, both in terms of ethnicity/ethnicity, religion and belief, and culture. This condition makes the Indonesian nation a multicultural nation that is unique compared to other nations in the world. The multicultural condition of the Indonesian nation is not caused by the arrival of various flows of refugees and immigrants from other countries. Multicultural conditions come from the trip and the reality of Indonesian history in the one caused by the geographical position of Indonesia in the cross-civilization of the world and in his capacity as an archipelago (archipelago).

In theoretical and practical experience of life as a nation, a patterned condition multicultural society ambiguous. On the one hand, multicultural conditions will provide richness in life experiences because various differences, whether ethnicity, religion and belief, or culture, will provide the best experiences (best practices). But on the other hand, the condition of the nation which is multicultural in nature provides a high chance of horizontal conflict. Various horizontal conflicts that hit partsof Indonesia before and in the early 2000s became evidence of the potential for horizontal conflicts contained by a multicultural society. So intense horizontal conflicts that occur so Sutherland (2000) states that the Indonesian nation has thepotential to become a divided society (the divided society).

In its development as a nation, all the uniqueness inherent in the multicultural Indonesian nation gets its ideological and philosophical umbrella from Pancasila. For the Indonesian people, Pancasila is the basis of the state's philosophy, outlook on life as well as the ideology of the nation. As the basis of thestate philosophy, Pancasila is a guide as well as a role model for the Indonesian people in living life as a nation and state. In its position as the nation's view of life, Pancasila is a source of values and morals for the Indonesian nation, so that its functionand role is to be the source of all sources of law (source oflegal order) of all existing legislation in Indonesia. Pancasila as the state ideology will unite all the steps as well as become the vision of the Indonesian nation in navigating life now and in the future.

On the way as a nation, the Indonesian people seemed to have forgotten Pancasila as the basis for philosophy, way of life, and state ideology, namely after the end of the New Orderregime, and the start of the reformation era in 1998 until the general elections in 2009. Ideology of fundamentalism and radicalism, especially in the religious field, causing various conflicts and social violence in society. At the same time, it is felt that the values of gotong royong, tolerance, and togetherness in society are fading. In fact, it is these values thatsupport the integration of the multicultural Indonesian society. The fading spirit of togetherness in society on the one hand and the strengthening of fundamentalism and radicalism will seriously threaten the equality of positions between humans. Only by developing an understanding of equality of position between various groups in society can national integration be maintained and maintained.

The concept of equality between humans in Parekh's view (1997) which departs from a multicultural perspective, 
"humans are naturally equal but not culturally equal". From that perspective, it can be interpreted that by nature humans have human right. In his position as a citizen, there is a legal guarantee that every citizen in the implementation of their rights and obligations is protected by the constitution in the personal, socio-cultural, economic, and legal fields.[1]

However, culturally people do not have equality, since it relates both competence and capacity in the fields of politics, economics, and power (power). This condition causes

stratification in social life. For example, from an economic perspective, there are groups of owners of capital and workers, in the political field there are groups of rulers and those who are controlled, and socially in the grouping there is stratification or social class. In general, social class is divided into three groups, namely the elite, middle class and grassroots.

Ontologically the concept of equality rests on a multicultural view. Thus the concept of equality contains two things, namely (1) freedom and opportunity to be different, and

(2) equal treatment for different groups[1].

Freedom to be different means freedom and the opportunity to become a group outside the dominant culture (mainstream), namely the choice to become a marginal group (non-mainstream). The aspect of equal treatment is related to the politics of recognition for various cultural groups, both those that are dominant cultures, and those of the periphery, so that in the concept of equality there are awards and politics of recognition. Lois Gosset Jr stated that: there is no tolerance without respect, and there is no appreciation without recognition, and finally no recognition without knowledge. So if reversed the order, the first is knowledge that will lead to recognition, recognition will lead to appreciation, and appreciation will lead to tolerance.

Meanwhile Banks (2008) states that are fundamental challenge for the community is the multicultural character of balancing between unity and oneness (unity) and at the same time maintaining the diversity (diversity). He added that maintaining unity and integrity without being accompanied by efforts to maintain diversity would lead to hegemony and oppression. On the other hand, maintaining diversity without an intention to unite will lead to Balkanization and the destruction of the nation-state[2].

Based on the above description, the main problem faced bynation states in the world today is how to recognize and legitimize differences and construct a national identity that accommodates the various voices, experiences, hopes of the different groups that make up the nation state[3].

The transformation of multicultural values to all citizens ofthe nation is carried out in various ways, one of which is through formal education. At the university level, this is done through curricular and non-curricular pathways. The curricularpath is carried out through lectures with general subjects and fields of study. In the general field course, it is explicitlycharged to the Pancasila Education and Citizenship Education courses. As for the subjects in the field of study, they are moreinclusive, namely the values taken from each subject that are associated with the values of Pancasila as the basis of the state and the nation's view of life. Extracurricular efforts are made through various field activities, practical, adapted to the talents and interests of students, and are complementary to curricular activities.

Pancasila education will provide content related to the role of Pancasila as a view of life, the basis of the state, and the nation's ideology to students. Through effective lecture activities, it is hoped that the values of Pancasila will be internalized to students so that it will strengthen their belief in the truth of Pancasila so that they are not easily swayed. The

udder in the dynamics of the nation's life which is strongly influenced by globalization. Pancasila education is more theoretical in nature because it emphasizes the aspects of coherence and correspondence between the values of Pancasilaand the reality of life for the Indonesian people. While Civics ismore applicable because the principle applies the values of Pancasila by citizens in living together as a nation-state. The problem is how Civics also incorporates the global valuesneeded to work for equality and social justice in the world[4]. This is because a human being apart from being a citizen and nation, is also a citizen of the world.

For this reason, it is time for efforts to build the moral values of the younger generation in the form of building a tolerant attitude, respecting diversity, developing respect for other social groups, and forming recognition of group diversity. How can awareness of religious tolerance Youth millennial Surabaya has in the dynamics of diversity

Suparlan sees multiculturalism as an ideology that glorifiescultural differences or beliefs that recognizes and encourages the realization of cultural pluralism as a mode of public life. The model of multiculturalism which emphasizes the recognition of equality of differences is different or even contrary to the model of "multiculturalism" which emphasizes the unity of existing cultures as a unit of uniformity. In the monoculturalism model, the dominant culture carries out assimilation or isolation policies and even genocide against ethnic groups classified as minorities[5].

One of the challenges for diverse nation-state democracies (such as Indonesia's) is to provide opportunities for different groups to maintain the cultural aspects of their society while building a nation in which these groups are structurally included and to which they give their allegiance. A balance of diversity and unity must be an important goal of democratic states and for the teaching and learning of democratic societies.Unity should be an important goal when nation-states respond to diversity in their populations. They can protect the rights of minorities and allow various groups to participate only when they are united by a set of democratic values such as justiceand equality[6].

It shows that everyone can respect each other regardless of the differences in their backgrounds, both physically and psychologically. This is because actually every human being lives side by side and must be able to foster mutual respect for one another. Religious tolerance is tolerance that contains belief in human beings related to faith and the God they believein. A person is given the freedom to believe in and embrace thereligion of his choice and to give respect for the implementation of the teachings he adheres to. Every human being has the full right to choose, embrace and believe according to his conscience. No one can force his will. For this reason, religious tolerance is very important to create religious harmony.

In carrying out life in the construction of a state that 
incorporates the values of tolerance, it is very important to apply it in various fields of life. Both in carrying out political, educational, economic, social and cultural activities. If tolerance is abandoned and acts of intolerance will occur, there will be divisions between fellow human beings.

\section{METHODS}

This study uses a qualitative approach with a qualitative descriptive design, with the consideration of revealing problems naturally without intervention from researchers. Thisresearch activity was carried out in the Surabaya area. The selection of this location was based on the consideration that the city that received the best tolerance level in the Setara Institute report.

The subjects in this study were students. Subjects were selected based on purposive sampling considerations. The number of subjects in the study will determine the adequacy of the data obtained.

The source of data that the author uses in this study is the type of primary data and secondary data, where primary data isdata directly collected by researchers from the first source. Theprimary data in this study are field findings derived from interviews with informants in the field. Secondary data is data obtained indirectly in the form of documents, which can also be said as additional data that is used as a reference and elaboration of primary data. Secondary data in the form of books, research journals, research documents, information from the mass media and so on, regarding tolerance to strengthen primary data. The author also uses researchdocuments in the form of journals and mass media regarding awareness of religious tolerance.

The data analysis technique used in this research is descriptive qualitative, using the Mills and Huberman model asfollows. They are data presentation, data reduction and conclusion.

\section{RESULTS AND DISCUSSION}

\subsection{Awareness millennial religious tolerance of diversity}

Awareness of religious tolerance, especially for millennial youth, can be identified with the construction of knowledge that is built regarding tolerance and also the application of tolerance values that are upheld when interacting with each other to respect each other between religious communities as aform of awareness of religious tolerance for millennial youth inSurabaya.

Knowledge of religious tolerance has been well constructedboth in knowledge and in attitude. Knowledge of tolerance, theimportance of tolerance, and the purpose of tolerance in the dynamics of diversity have been well constructed, according to 21-year-old Reynaldi.

“...The definition of tolerance itself is an attitude of mutual respect for one another in various aspects, for example in the aspect of ethnicity, religion, class, race, and others. Tolerance can often be found in the surrounding environment where the majority of the people have an open mind and do not like to interfere in other people's affairs. Around me, tolerance can be found, for example, if there are Muslim neighbors who want toprepare a place/location for taraweh prayers at the RW hall, non-Muslim neighbors work together to help prepare a place that can be used as a place for prayer. Taraweeh prayers start from cleaning the RW hall building, preparing large carpets, etc. so that the creation of inter-religious tolerance can be implemented (in the context of not participating in their worship but helping in other ways or in this case, helping to facilitate). And vice versa, if my non-Muslim neighbors need any kind of help, the majority of the people around me help each other regardless of their religion..." (Reynaldi, 21 Years Old) (Primary Data Source: Wednesday, September 22, 2021)

Not only 21-year-old Reynaldi who has contextual knowledge of tolerance, but 21-year-old Ruth Gabrielala also conveys the meaning of tolerance according to her understanding, namely:

"...In my opinion, tolerance is an attitude of respect that wemust apply in social life, and usually tolerance is between religious people, inter ethnic groups, etc., ma'am. I think it's very important, ma'am, because of this tolerance, we respect orrespect differences, ma'am, so it's important for me that no one feels belittled, or feels unappreciated, or offended, ma'am..."(Ruth Gabriella, 21 Years) (Primary Data Source : Wednesday, September 22, 2021)

The same understanding was also conveyed by the 21 year-old millennial Pande Made Yonata regarding tolerance knowledge, namely:

“...religious tolerance is an attitude of respect and respect for other religions. S, effectively, is very important because inIndonesia is not only a religion, but now many people who insult each religion even insulted his Lord but says cuman jokes. .." (Pande Made Yonata, 21 Years Old) (Primary Data Source: Wednesday, 22 September 2021)

When analyzed regarding the awareness of interreligious tolerance among millennial youth in Surabaya through the construct of knowledge that is built, Reynaldi is a Muslim, Ruth Gabriella is a Christian, and Pande Made Yonata, a Hindu, has good knowledge of tolerance, the importance of tolerance and goals. Tolerance so that it can be said that all three have awareness of religious tolerance in realizing the dynamics of diversity. Reynaldi 21 years as a Muslim who hasan awareness of religious tolerance is finally able to practice his inner awareness to help each other without paying attentionto the religious background in the surrounding environment. Furthermore, a lack of awareness of religious tolerance for Pande Made Yonata 21 years also lead to the realization that a joke based on religion can not be taken for granted because it isable to create friction between religious communities lainnyamso Ruth Gabriella 21 years and Pande Made Yonata 21 years agreed that harmony It is important for religious people tobuild the dynamics of religious diversity through awareness of tolerance between religious communities

\subsection{Implementation of Tolerance Values in Inter- religious Interaction}

Awareness of religious tolerance for millennial youth in Surabaya must also be harmonized with the application of prioritized values in interacting with others in the hope of being able to create harmonious dynamics of religious diversity. The application of principles in interacting is also 
a form of respecting the beliefs of others around them, so that according to Reynaldi, 21 years of age, what is important from awarenessof tolerance is the application of values:

"... The values that must be upheld in socializing are first , namely tolerance itself because with tolerance, people will helpeach other and no one hates each other which can lead to division and if it gets worse, the victims who falling will be a real threat, for example, the breakup of the Yugoslav state due to inter-ethnic clashes so that many civilians are killed, secondly, namely sympathy where our hearts will be driven todo good and help others who are in trouble in any form so that our relationship between other communities are gettingstronger and social and economic disparities can be overcome. Third, namely solidarity, where every layer of society synergizes with each other to prioritize common interests and ifthere is a problem, the problem will be quickly resolved with the solidarity ..." (Reynaldi, 21 years old) (Primary Data Source: Wednesday, 22 September 2021)

Not only, the value of tolerance Ruth Gabriella but also explained the importance of the value of unity in interreligiousinteraction as a form of awareness of inter-religious tolerance, namely:

"...My principle is ma'am, we must respect any differences in any aspect, ma'am, such as religion, ethnicity, differences inrace, skin color, hair, and so on. The value, in my opinion, ma'am, is the value of Unity, ma'am, because if we want to unite, ma'am, regardless of anything, surely what we plan together or what we want to do together must be achieved, ma'am, and that has also been regulated by the 1945 Constitution, Article 28E 1-3, because I myself feel that I have the freedom to embrace the religion I believe in..." (Ruth Gabriella, 21 Years Old) (Primary Data Source: Wednesday, September 22, 2021)

In addition to Ruth 21, Pande Made Yonata, 21, also conveyed the existence of shared rights that must be upheld in interaction between religious communities, namely:

“...Tolerance, ma'am, because of their rights, they must have the freedom to carry out their obligations such as worship and other religious events. I want to interact normally without regard to other religions being different and that is important because if there is no peace, there will be many disputes and the interaction is useless. If tolerance awareness is still minimal, people will feel that their religion is of the highest degree. Of course, now if we realize that all religions are the same then life will be peaceful and no one looks down on each other. Of course. By respecting and respecting other religions, Irealize that I respect people of other religions and do notdiscriminate. After all, we have nothing to lose if we tolerate each other..." (Pande Made Yonata, 21 years old) (Primary Data Source: Wednesday, September 22nd) 2021)

If the analysis in the application of values that are upheld in interaction as a form of awareness of religious tolerance, Reynaldi 21 years as a Muslim, Ruth Gabriella 21 years as a Christian, and Pande Made Yonata 21 years as a Hindu believer agree that awareness of religious tolerance is also current. Balanced by the application of values that are upheld in interaction, the three agreed to establish interreligious relationships, the value of tolerance is the main value because if the value of tolerance continues to be upheld in interacting, it will create the dynamics of harmonious religious diversity in the community. Surrounding environment awareness of religious tolerance for millennial youth can not only be done with the knowledge that is built, but also must be balanced with the skills for habituation of religious tolerance in the surrounding environment. This means that this awareness cannot only be limited to understanding, but must also be carried out in real terms in the surrounding environmentregarding awareness of religious tolerance

The skills for habituation of religious tolerance by millennial youth in Surabaya have also been well formed in an effort to realize the dynamics of diversity, for example 21year- old Reynaldi who has habituation skills in his environment as follows:

“...In my opinion, I already have an awareness of toleranceand can even apply it in the environment around me. Why so? Because I have several opinions, first, I think that tolerance should be upheld indiscriminately towards anyone, because with this attitude, no individual will feel marginalized or even have a grudge against one another. Second, tolerance plays an important role on a national scale, if people help each other regardless of religion/ethnicity/race, our relationship as Indonesian citizens will be closer and divisions within theUnitary State of the Republic of Indonesia will most likely be avoided because of tolerance and imagine if the majority of the Indonesian population has high levels of tolerance. Low tolerance for example terrorist groups in Poso who think that their religion is the best of all and because of their low tolerance level, anyone who does not agree with them can easily be killed without mercy. If this happens on a national scale, civil war can occur and cannot be avoided, and lastly, I think having mutual tolerance is an easy thing and not at all difficult to carry out and the conditions around our society will become cooler if the Indonesian people realize this instead of blaspheming each other which in my opinion is hard because ittakes time and energy and even then it has a negative impact on the parties involved..." (Reynaldi, 21 Years Old) (Primary Data Source: Wednesday, 22 September 2021)

Furthermore, the same thing was also conveyed by 21year-old Pande Made Yonata that:

"... almost all of my friends are Muslim they still want to befriends with me, that means they don't distinguish friends fromdifferent religions, from my friends are Muslims but I still respect their religion and they respect my religion, the first onemust respect it, usually when there is a religious event said, even I also lawful gatherings, my attitude if the neighbors do not interfere with my religious activities such as playing loud music or screaming shout or also play basketball etc. the activities which can be annoying if it were not done ... " (PandeMade Yonata, 21 years old) (Primary Data Source: Wednesday, 22 September 2021)

When analyzed interviews among Reynaldin 21 years as a Muslim in Pande made Yonata as Hindu religious communities, both have the ability to familiarize themselves with the tolerance of religion in the surrounding environment. 21-year-old Reynaldi said that in everyday life, he adheres to the value of tolerance in interactions because Reynaldi already has a good awareness of the importance of tolerance, the same thing was conveyed by 2 -year-old Pande Made Yonata, who himself interacted with Muslim friends 
who different from himself, Pande Made Yonata upholds tolerance in building friendship relations so that between the two there has been an implementation of tolerance through awareness of the importance of religious tolerance. This awareness of tolerance, which is balanced with the skills of religious tolerance in the environment around them, is what finally led Reynaldi, 21, and Pande Made Yonata, 21, as millennials in Surabaya, to have awareness of the importance of religious tolerance in realizing religious diversity in harmony in their respective environments.

Awareness of religious tolerance in Surabaya millennial youth has been well developed which in the construction of knowledge that is built, Reynaldi 21 years old, Ruth Gabriella 21 years old, and Pande Made Yonata 21 years old have good knowledge about the meaning of religious tolerance, the importance of religious tolerance, and the goal of religious tolerance. The three agreed that this tolerance is briefly defined by respecting the differences that exist, especially in religious differences. Reynaldi 21 years old as a Muslim in the surrounding environment has held the value of tolerance as a priority in interacting with religious people in his environment, the same thing was also done by 21 years old Ruth Gabriella and 21 year old Pande Yonata, Ruth Gabriella as a Christian realizes and upholds the implementation of values tolerance in fellow religious people and also Pande Made Yonata, who is 21 years old as a Hindu, respects other religious people by, for example, participating in respecting religious days in the surrounding environment, such as participating in halal bihalalactivities in the surrounding environment. This awareness of religious tolerance has finally led Reynaldi 21 years old, Ruth Gabriella 21 years old, and Pande Made Yonata 21 years old tohave the skills to habituate religious tolerance in order to realize the dynamics of religious diversity in their respective environments.

It is this well-developed awareness of tolerance that finallyled Reyna $1 \mathrm{~d}$ i at 21 and Pande Made Yonata at 21 to each have the habituation skills of religious tolerance. Both of them not only have well-developed knowledge contextually but are also able to implement that knowledge in the surroundingenvironment so that the awareness pattern that appears in Surabaya millennial youth is a dynamiccreative awarenesspattern.

The pattern of dynamic awareness is that a person achievesa creative self-awareness capable of seeing the truth objectively without being distracted by his subjective feelings and desires. This stage can be obtained, among others, through religious, scientific or other activities outside of routine activities. This awareness has also been owned by 21-year-old Reynaldi, 21- year-old Ruth Gabriella, and 21year-old Pande Made Yonata which as a result of the awareness of religious tolerance for thethree as millennial youths are finally able to realize religious diversity in their respective environments.

\section{CONCLUSION}

Awareness of religious tolerance in their surrounding environment, as evidenced by the construction of knowledge related to good tolerance and to the implementation of tolerance awareness in their respective environments. So not only have awareness of religious tolerance but also have the skills to habituate religious tolerance in their surrounding environment so as to form a dynamic-creative awareness pattern. Awareness of religious tolerance for millennial youth in Surabaya in realizing harmonious religious diversity is obtained through education, especially Pancasila and Citizenship Education in their respective schools.

\section{ACKNOWLEDGMENTS}

I would like to thank all parties involved in this research, Dean and also Universitas Negeri Surabaya.

\section{REFERENCES}

[1] B. Parekh, Rethinking Multiculturalism.Keberagaman Budaya dan Teori Politik. Jakarta: Kanisius, 2008.

[2] Banks, James A., "Diversity, Group identity, and Citizenship education in a Global Age," Educ. Res., vol. 37, no. 3, pp. 129-139, 2008.

[3] audry Osler, "Citizenship Education and the Ajegbo report: re-imagining a cosmopolitan nation," London Rev. Educ., vol. 6, no. 1, pp. 11-25, 2008.

[4] M. Nassbaum, "Transcendence and Human Value," Philos. Phenomenol. Res., vol. LXIV, no. 2, 2007.

[5] Suparlan, Hubungan Antar Suku Bangsa. Jakarta, 2004.

[6] Banks, James A., "Educating Citizens In Diverse Societies, Intercultural Education," Educ. Res., vol. 22, no. 4, pp. 243-251, 2011. 